\title{
Jogismeret a közoktatásban
}

Elóadásomban arra keresem a választ, hogy a közoktatásban szükség van-e a jelenleginél elmélyültebb jogi tudásátadásra és a diákok, pedagógusok, iskolaigazgatók jogismeretének fejlesztésére. Azt vizsgálom, hogy a szükségesnek itélt jogi ismeretek elsajátítására milyen lehetôségek, milyen - más országokban már kipróbált módszerek állnak rendelkezésre, és ezekból mit érdemes Magyarországon alkalmazni, amennyiben erre vonatkozó igény artikulálódik.

A mennyiben a „kettős iskolarendszer” (Ferge, 1984) koncepciójának gyakorlati megvalósulására, azon belül a felülről lefelé kiépülő oktatási szisztémára kellene tökéletes példát találni, akkor a jog oktatásának mikéntje kiválóan alkalmas lenne az elmélet igazolására. Annak ellenére, hogy a társadalmi együttélést és a társadalmi konfliktusok feloldását rendező normák ismeretének átadásáról van szó, a közoktatási rendszerbe mindmáig csupán elenyésző ismeretanyag „,csorgott le” a felsőoktatásból, és középfokú végzettséggel rendelkezők tömege tekinthető a jogismeret szempontjából bizonyos értelemben analfabétának. Ez a világszintü jelenség különösen annak ismeretében érdekes, hogy mindeközben kevés jogelv számíthat annyira ismertnek, mint az „Ignorantia juris non excusat”, ami példának okáért Magyarországon olyan nyakatekert változatban vált elterjedtté, hogy „A jog nem ismerete nem mentesít”.

Ennek a köztudatba vésődött maximának az értelme arra a gondolatra vezethetne minket, hogy az államok nyilvánvalóan mindent elkövetnek annak érdekében, hogy a közoktatásból kikerülők kellő jogismerettel felvértezve váljanak jogkövető állampolgárrá. Amennyiben a legalapvetőbb, a mindennapi életet meghatározó jogi normákat egy diák ismeri, talán nagyobb az esélye annak is, hogy e normákat később tiszteletben tartja. A jogtudomány régóta tisztában van azzal, hogy a jogismeret és a jogszabályszerü viselkedés nem feltétlenül függ össze. Legfőképpen azért, mert a jogismeret „...csak egyik eleme a cselekvésre vonatkozó ismereteknek, továbbá, mert a cselekvés meghatározásában a kogníción kívül emocionális erők is hatnak, amelyek kizárhatják az ismeret alkalmazását..." (Sajó, 1980, 260. o.). Mégis, könnyen belátható, hogy a jogismeret egy bizonyos szintjére szükség van ahhoz, hogy jogkövető szándék esetén valaki jogszerúen is cselekedhessen.

Mindezek alapján feltételezhető lenne, hogy az iskolarendszer mindent megtesz azért, hogy a diákok esélyt kapjanak arra, hogy az egyre komplexebb jogrendszer útvesztőiben könnyebben eligazodjanak, és a mindennapi életben rendszeresen előforduló tranzakciók alkalmával, egy szimpla adásvétel kapcsán, vagy éppen egy önkormányzati választás, hivatali ügyintézés esetén jogaikkal tisztában legyenek. Ám nem pusztán a diákok jogismeretének hiánya, hanem a közoktatás egyéb aktorainak jogismerete is hasonló következtetésekre adhatna okot és megválaszolásra váró kérdéseket vethetne fel.

A közoktatási rendszerben nem feltétlenül csupán a diákok jogismeretének szintje lehet problematikus. Hasonlóan izgalmas kérdés az is, hogy a tanárok vagy az oktatás adminiszt- 
ratív vezetői jogismeretének milyen szintjére lehet szükség ahhoz, hogy az iskola, a tanárok és legföképpen a diákok érdekei ne sérüljenek. Léteznek ugyanis szituációk, amikor nincs idő és sok esetben pénz sem ügyvédi irodához fordulni egy akut, jogismeretet igénylö probléma megoldásához. Legyen szó munkajogi, fegyelmi vagy éppen esélyegyenlőségi kérdésröl, a tanárok, iskolaigazgatók könnyen szembesülhetnek azzal, hogy egy ügy megoldásához nincsenek kellő jogi szakismerettel felvértezve. Ahol nem létezik iskolajogász (ellentétben más országokkal), ott a tanárok (vagy adminisztratív vezetők) kénytelenek ilyen helyzetben felelősséget vállalni, és gyakran kényes kérdésekről dönteni.

E probléma alapos elemzésére és vizsgálatára az Egyesült Államokban került sor, ahol régóta folynak e kérdésre irányuló szociológiai kutatások. Az egyik kutatócsoport (Fischer, Schimmel és Stellman, 2007) tanulmányában azt állította, hogy számos olyan, a tanárok, diákok, szülők életét befolyásoló jogesetről lehet tudni, ahol az iskolaigazgatók jogismeretének hiánya tehető felelössé az alkotmányos jogok sérüléséért és bizonyos esetekben az ebből fakadó kártérítési összegek megítéléséért. Schimmel és Militello (2007) végezte el az egyik legátfogóbb kutatást e téren, akik 1300 iskolaigazgatót kértek fel arra, hogy egy ,iskolajogra” vonatkozó tesztet töltsenek ki 17 amerikai tagállamban. Megállapításuk szerint alapvető, a közoktatásban érintettek jogaira vonatkozó kérdések felére nem tudtak a megkérdezettek korrekt választ adni. Ugyancsak megállapították, hogy az iskolaigazgatók 75 százaléka jelezte, hogy nem részesültek korábban iskolajogot oktató programban, miközben ennek szükségességére hívták fel a kutatók figyelmét. Eberwein 2008-ban mindezt 77, hasonló kérdésre vonatkozó kutatás összegzésével támasztotta alá, melyek jelentős többsége az iskolaigazgatók elfogadhatatlanul alacsony jogismeretét mutatta ki (Eberwein, 2008). Eberwein javaslata az, hogy a pedagógusképzésbe az iskolajog oktatását mindenféleképpen integrálni kellene.

Ez a jelenség nyilvánvalóan nem korlátozódik az Egyesült Államokra, és a pedagógusok jogismeretét kutató vizsgálat Magyarországon valószínüleg hasonló eredménynyel zárulna. Ezt nem csupán a középiskolai pedagógusokkal folytatott személyes beszélgetések támaszthatják alá, hanem az a tény is, hogy általános jogismeretet és célzott iskolajogot magába foglaló oktatási program sem a pedagógusképzésben, sem a pedagógus-továbbképzésben komoly formában nem kap helyet. Jóllehet az „Iskolajog” bizonyos elemei (mint pl. az Oktatási Jogok biztosának eljárásaiból összeálló „esetjog” anyaga) szerepet kapnak a pedagógusok képzésében, ám ez az igen komplex, az iskolák szempontjából releváns joganyag töredékét jelenti csupán. Amennyiben megvizsgáljuk a Közoktatási vezetőképző programok tantárgylistáját, szembetünő a jogi jellegü tantárgyak alulreprezentáltsága, és az, hogy e tárgyak az általánosság szintjén maradva „Jogi alaptan" szintü ismeretek átadására szorítkoznak csupán, vagy maximum jogági alapokkal ismerkedhetnek meg a képzés résztvevői. Azoknál a képző intézményeknél, ahol jogi karok is müködnek, nyilvánvalóan komolyabb lehetőségek lennének elmélyültebb jogi kurzusok integrálására, ám ezen oktatási intézményeknél is érzékelhető az ilyen jellegü programoktól való ódzkodás. Ma is érvényes megállapításnak tekinthető Bíró Endre (1998, 42. o.) gondolata, miszerint a ,pedagógiai gyakorlat a jogot, jogalkalmazást, jogi normativitást nem tekinti a pedagógia külön is említendő tételeinek”.

Véleményem szerint ma Magyarországon is szükségesnek látszik egy iskolajog elnevezésű tantárgy kidolgozása, melynek oktatása speciális, a pedagógusok igényeihez és előismeretéhez igazított módszertan alapján járulhatna hozzá a pedagógusok, majd később az intézményvezetők képzéséhez. Egy ilyen tárgy nem szorítkozna csupán az iskolákat közvetlenül érintő jogforrások ismertetésére, hanem magában foglalhatná az alapvető alkotmányjogi, közigazgatási, munkajogi, büntető és polgári jogi ismereteken túl azon, elsősorban az iskolák müködési körében felmerülö jogi problémák esetjogi jellegü feldolgozását is, melyek a tanárokat, az intézményvezetőket a napi ügyintézési feladatok elvégzésében segíthetik. 
A 2012-ben elfogadott Nemzeti Alaptanterv a jogi ismeretek átadásának formáit módosította a közoktatásban, ám lényegét tekintve komoly változást ez nem jelent. Továbbra is a jog világának egy szük szelete épül be a tantervbe, amely mindenekelött az állampolgári jogokra és kötelességekre, az Unió intézményrendszerére, a választási rendszerre és általában a demokratikus társadalmi berendezkedés eszköztárának bemutatására korlátozódik, némi munkajogi ismeretanyag integrálásával. Az például, hogy az állampolgári ismeretek oktatása beépül a történelem oktatásába (történelem, társadalmi és állampolgári ismeretek), akár módszertani szempontból még hasznos is lehet, hiszen a diákok így a korábban külön tálalt ismeretanyagot történelmi összefüggésben dolgozzák fel. Úgy gondolom azonban, hogy a probléma gyökerét nem elsősorban ott kell keresni, hogy hány órában, milyen keretek között oktatnak jogot a közoktatásban, hanem hogy azt milyen hatékonysággal teszik.

A magyar jogismereti kutatások a rendszerváltást megelőzően Kulcsár Kálmán és Sajó András munkásságának köszönhetően váltak ismertté. A rendszerváltást követően is folytak bizonyos társadalmi csoportok jogismeretére vonatkozó vizsgálatok (Kulcsár, 1967; Sajó, 1986; Kormány, 1998; Visegrády és Schadt, 2000; Kelemen, 2009). Azt, hogy a magyar középiskolás diákok szerény jogismerettel rendelkeznek, több kutatás is alátámasztotta. Az egyik legátfogóbb, a diákok jogismeretét is firtató vizsgálatot a 2001-2002-es tanévben az Oktatási Jogok Miniszteri Biztosának Hivatala megbízásából végezték el (Ligeti és Márton, 2001). A kutatás során kvantitatív és kvalitatív módszerekkel vették górcső alá az ,iskolapolgárok” jogainak érvényesülését, melynek során a kutatók arra is kíváncsiak voltak, hogy a diákok jogaik érvényesíthetősége céljából milyen mértékü jogismerettel rendelkeznek. A vizsgálatot végzők maguk is hangsúlyozzák, hogy a jogismeret a ,jogtudatos” magatartás kialakulásához szükséges, de nem elégséges feltétel. Többre, mindenekelőtt jogszerúen működő iskolai keretekre van szükség annak kialakulásához.

A 60 osztályt lekérdező csoportos mintavételi eljárás során 11. évfolyamos diákokat kérdeztek meg a diákok iskolához, munkához való viszonyától kezdve a jogtudatosságon át a jogismeret kiterjedtségéig számos olyan kérdésről, melyek jogaik érvényesülésével függhetnek össze. A jogismeret kiterjedtségét a diákönkormányzat jogosítványainak, a házirend tartalmának és a hatalmi ágak szétválasztásának témakörében vizsgálták. A kutatás jogismeretre vonatkozó konklúziói közül sokatmondó az, hogy míg a diákönkormányzatokra vonatkozó jogokat viszonylag jól ismerik a diákok, addig a hatalmi ágak elválasztásához kapcsolódó kérdésekről a megkérdezetteknek csupán 13,8 százaléka rendelkezett megfelelő ismeretekkel (Ligeti és Márton, 2001, 27. o.). Mindez azzal az eredménnyel egészíthető ki, hogy a magasabban kvalifikált képzési típusokban részt vevő diákok magasabb jogismereti szinttel rendelkeznek (Ligeti és Márton, 2001, 31. o.).

A fenti kutatás nem vizsgálta a diákok jogismereti szintjét olyan területeken, amit a közoktatás Magyarországon következetesen kihagy a képzésből. Sem a polgári, sem a büntetőjogi ismeretekre nem tért ki e vizsgálat, hogy csupán az általános, és a mindennapokat leginkább átható jogi tudás szempontjából releváns jogterületeket említsük. A kutatás számunkra legfontosabb konklúziója az lehet, hogy azokon a jogi területeken, amelyek a közoktatás integrált részét képezik, alacsony a jogismereti szint, tehát az oktatás hatékonysága is feltehetően alacsony. Ugyanakkor ez a kutatás is megerősítette azokat a korábbi vizsgálatokat, melyek a jogismeret szintjének pozitív változásánál az oktatás szerepét az egyik legfontosabb tényezőként értékelik.

Gajduschek György és Fekete Balázs (2014) 2014-es vizsgálatát érdemes még idézni, mely a legfrissebb és legátfogóbb jogismereti kutatás a rendszerváltás óta. A kutatók a teljes népesség jogismeretének mérését tüzték ki célul, és eredményeiket a korábbi (elsősorban a Kulcsár-féle 1965-ös) jogismereti kutatások eredményeivel kívánták összevetni. A rendkívül érdekes felmérésböl is az emelhető ki, hogy a kutatók a szignifikancia-érté- 
kekre tekintve egyedül az iskolai végzettség esetében találtak egyértelmű összefüggést a teljes jogismerettel. „Napjainkban az iskolai végzettség szerepe domináns, és minden más tényező látszólagos hatása mögött is elsősorban e tényező sejlik fel" (Gajduschek és Fekete, 2014, 32. o.). A kutatásból érdemes még kiemelni azt, hogy míg az ,alkotmányjogi" ismeretszint általános emelkedésére derült fény a ' 60 -as évekhez képest, a jogismeret szintjének radikális csökkenése volt mérhető a polgári jog területét érintő kérdésnél.

Mindebből talán nem túl merész következtetés az sem, hogy a társadalom jogismereti szintje a közoktatás színvonalával, azon belül a joggal kapcsolatos ismeretek oktatásának hatékonyságával is összefüggést mutat. Érdemes tehát foglalkozni azzal, hogy a közoktatásban milyen szerepet szánjunk a jogismeret fejlesztésének.

Amennyiben arra keressük a választ, hogy mit és milyen formában lenne érdemes a közoktatásban a jog témaköréből oktatni, akkor máris kettéválasztottuk az előadás két alapkérdését a tartalom és módszertan problematikájára. Mindkét kérdés kapcsán hangsúlyozni kell, hogy a nemzetközi szakirodalomban még a jogi felsőoktatást illetően sem beszélhetünk kiforrott, általánosan elfogadott álláspontról, amit a különböző államokban a jogászképzésben minimumkövetelményként elfogadnának.

A „mit oktassunk” típusú kérdésekre a nemzetállammá válást, a kodifikációt, ezzel együtt a jogrendszereket a jogi felsőoktatásban összekötő 'ius commune' elsorvadását követően logikus választ adtak az európai országok. Az egyetemeken a kánonjogon és a római jogon alapuló oktatást fokozatosan váltotta fel a nemzeti törvények ismertetését célzó jogászképzési gyakorlat, melynek alapját a nemzeti nyelven írt kódexek jelentették, és jelentik máig is. Míg a jogászképzést korábban a Codex Iuris Civilis alapozta meg, addig a 19. századtól kezdve napjainkig a nemzeti joganyagok bázisát jelentő jogforrások. Azzal kapcsolatban, hogy ezen túl milyen alapozó tárgyakkal, a jogászi műveltséget fejlesztő stúdiumokkal töltik ki a joghallgatók egyetemi éveit, rendkívüli változatosságot tapasztalhatunk. Míg a középkori jogi diploma bizonyos kereteken belül univerzálisnak számított, manapság jóval nehezebben konvertálható, és a nemzeti sajátosságokhoz inkább illeszkedő tudásanyagot biztosít megszerzője számára. A középkorra jellemző joghallgatói mobilitás egy „univerzális” tudásanyag kialakítására ösztönözte az európai jogi fakultásokat, melyek felülről épültek ki (Nagy, 2007, 29. o.). Nem pusztán azért, mert tipikusan uralkodói akaratra jöttek létre, hanem mert alsó fokú oktatási bázis nélkül működtek, és egy latinul egymást jól értő európai jogász elit megteremtéséhez járultak hozzá, mely elit az így megszerzett kiváltságait évszázadokon át féltve őrizhette. Ilyen keretek között válik érthetővé, hogy a mindennapi életben is elengedhetetlennek számító jogi alaptudás megszerzésének lehetősége miért nem válhatott általánossá a közoktatásban.

Azt a kérdést, hogy az általános és középiskolákban milyen jellegü és szintü jogi ismeretet lenne érdemes átadni a diákoknak, a nemzetközi példák ismeretében nehéz megválaszolni. Olyannyira különböző megoldásokat találhatunk az egyes országokban, amelyek nehezen igazíthatnak el bennünket ezen a területen. Vannak például uniós tagállamok, ahol az általános iskola első osztályától kezdve az érettségi megszerzéséig egy jól kidolgozott, több évszázados fejlődési folyamat eredményeként kialakult programon keresztül jut komoly jelentőséghez a jogi ismeretek megszerzése. Ilyennek számít a példának okáért Franciaország, ahol a francia forradalom óta fejlesztik az Állampolgárság elnevezésü tárgyat, mely számos tartalmi és módszertani változáson átesve ma más célok mellett komplex jogi ismeretek megszerzését is biztosítja a francia diákoknak. Ahogyan e tárgy fejlődéstörténetét feldolgozó szerző (Galichet, 2005, 14. o.) írásában megjegyzi, e tárgy mára elveszítette a nemzeti „közös szellem” kialakítására irányuló törekvését, és sokkal inkább az állampolgárok jogainak és kötelezettségeinek megismerésére koncentrál. Unión kívüli szomszédos országban is találunk példát arra, hogy az átlagosnál nagyobb figyelmet szentelnek a jogismeret fejlesztésének, és általában a jog szerepének 
a közoktatásban. Szerbiában például nem csupán külön „,iskolajogászt” alkalmaznak az iskolavezetők tevékenységének támogatására, hanem a gimnáziumokban kötelező Alkotmány és (állam)polgárjog címü kurzus választható érettségi tárgy is, melynek keretein belül jogi alapismereteket sajátítanak el a tanulók. Ugyanakkor mintaadó jogrendszerekben (pl. Németország) is megfigyelhető a jog szerepének marginalizálódása a közoktatásban, ahol a jogi ismeretek fejlesztése a demokratikus társadalmi berendezkedés jogi kereteinek megismertetésére szorítkozik elsősorban.

Amennyiben más oldalról, a társadalmi igények felöl közelítjük meg a kérdést, biztosabb kapaszkodókhoz jutunk a kérdés megválaszolásához. A korábban kifejtetteknek megfelelően egy általános, alapvető jogismereti szint kialakítása az állampolgárok minél szélesebb rétegében egy modern demokratikus társadalom hatékonyabb, „olajozottabb” működését eredményezheti. Csak a szélsőséges normativizmus képviselői gondolják azt, hogy az emberi magatartást a jogi normák határozzák meg. Arisztotelész óta tudjuk, hogy a jogkövető magatartás kialakulása elsősorban a szokásoknak és nem a jogi normák ismeretének, kényszerének köszönhető. Ugyanakkor nem tagadható le az sem, hogy a jogismeret szerepe a jogkövetés kialakításában jelentős. Mélyebb elemzés igénye nélkül az is állítható, hogy bár erkölcs és jog csak részben fedik egymást, a jogismeret fejlesztése a társadalmi morál alakításához is hozzájárul. Ezen általános szempontok tekintetbe vétele mellett a jog oktatását tartalmi szempontból az alábbi területeken tekinthetjük a közoktatás keretein belül szükségesnek:

A demokratikus jogállami berendezkedésre vonatkozó alapismeretek megszerzése. Ez az alkotmányosság klasszikus elveinek és az alapvető alkotmányos értékek, a képviseleti demokrácia müködési mechanizmusának megismertetésén túl magában foglalja az emberi jogokra, az Európai Uniót meghatározó jogi keretekre vonatkozó alapismereteket is. Ez az az ismeretanyag, ami a közoktatásban így vagy úgy, de szinte minden országban, így Magyarországon is helyet kap az alap- és középfokú oktatásban. (Jelentős különbség leginkább abban van, hogy hány órában, önálló stúdium formájában, vagy éppen a történelemórák keretében folyik az ilyen jellegü ismeretek oktatása.)

Polgári, munkajogi, közigazgatási és büntetőjogi alapismeretek. Piacgazdasági keretek között léteznek olyan jogdogmatikai fogalmak, melyek a mindennapok egyszerü tranzakcióinál vagy egy hatóságtól érkező hivatalos iratban okozhatnak félreértést az állampolgárok számára. Talán nem úgy, ahogy Móra Ferenc novellájában (Mihály folyamatbatétele) Mihály érti félre a „folyamatbatétele” kifejezést, azt hívén, hogy a Tiszába akarja vettetni őt a hatóság, de számos esetben a legegyszerübbnek számító jogi fogalmak is értelmezési nehézséget okozhatnak az állampolgárok számára. (Tapasztalatunk szerint például a ,jogi személy" kifejezést a középiskolások rendre félreértik, és joggal hivatalosan foglalkozó személyt, vagyis ügyvédet, bírót értenek alatta.) Miután az évezredes tendenciák fényében arra nem lehet számítani, hogy a jog nyelvezete közelítsen a hétköznapi nyelvezethez, ezért érdemes megfontolni a legalapvetőbb jogági szakkifejezések, ezzel együtt a legalapvetőbb szabályok megismertetését a diákokkal. A polgári jogi, munkajogi vagy közigazgatási jogi ismeretek haszna a hétköznapi életben tetten érhető. A büntetőjogi ismeretek elsajátítása ezzel szemben szélsőséges szituációkban és a bűnmegelőzés szempontjából nyerhet értelmet. (A középiskolás diákok általában ezen a területen mutatnak nagy érdeklődést, és döbbennek meg sokszor attól, hogy a diákcsínyeket milyen kevés választja el a súlyos szankcióval fenyegetett büncselekményektől.)

Amennyiben elfogadjuk a fent leírtak szükségességét, akkor rátérhetünk a nehezebb kérdés megválaszolására. Hogyan, és milyen keretek között érdemes ezekkel az alapvető ismeretekkel felvértezni a diákokat?

A jogi jellegü tárgyak oktatásának módszereit illetően is a változatosság gyönyörködteti a témában jártas kutatókat. Magyarországon Nagy Zsolt dolgozta fel a jogászképzésben elterjedt oktatás módszertani megoldásait, melyek ismertetésére ehelyütt nem 
vállalkozhatunk. Annak megállapítására azonban igen, hogy a magyar jogászképzés - szemben a német vagy éppen az amerikai módszertani megoldásokkal -, évszázadok óta szenvedi a memoriter jellegű feladatokra koncentráló oktatási tradíciót. Jóllehet már a 18. században konkrét intézkedés történt a „magoltatás”, a szó szerinti visszakérdezés ellen (Eckhart, 1936, 177. o.), az alapvető jogszabályok memorizálását megkövetelö oktatási szemlélet az újító törekvések mellett máig él.

Azt a kérdést, hogy a megjelölt tartalmak oktatását milyen módszerrel lehet és érdemes általános vagy középiskolás diákok számára hatékonyan megoldani, a felsőoktatási tapasztalatok alapján egyértelmüen meg lehet válaszolni. Még véletlenül sem abban a formában, ahogyan azt a jogászképzésben tesszük. Nyilván léteznek a magyar jogászképzésben is olyan megoldások, melyek a „poroszos” hagyományoktól eltérően, interaktív módon vezetik be a hallgatóság egyes csoportjait a jogági rejtelmekbe, ám a számonkérés módja a leadott tananyag szigorú visszakérdezésére koncentrál továbbra is. Az ilyen jellegü oktatási módszer a közoktatásban csupán arra lehet alkalmas, hogy a diákokat a jog világától elidegenítse. Nem részletezve a különböző módszertani lehetőségeket, mi amellett tesszük le voksunkat, ami a nemzetközi gyakorlatban már bevált, hatékonyságát pedig majdnem fél évszázados siker igazolja, és amelynek kereteit az elmúlt években Magyarországon is megteremtették már.

Az Országos Bírósági Hivatal $(\mathrm{OBH})$ létrejöttének körülményeit a bírói hatalom függetlensége szempontjából számos kritika érte. Azt, hogy ezen új igazgatási forma mennyiben teremti meg a bírói függetlenség sérelmének reális esélyét, ehelyütt nem célunk elemezni. Ugyanakkor érdemes megjegyezni, hogy bármilyen álláspontot képviselünk e vitában, a 2010 után megvalósított igazságszolgáltatási reform előnyös aspektusait nem szabad letagadni. A bíróságok igazgatását végző OBH a jogászképzésben és a középiskolákban folytatott ismeretterjesztő programok kapcsán elismerésre méltó szerepet vállal, és tevékenységével a fent vázolt célok megvalósításához járul hozzá.

Az igazságszolgáltatás nyitottsága jegyében Nyitott Bíróság címmel indítottak olyan előadássorozatot és ehhez kapcsolódó más, az igazságszolgáltatás müködését bemutató programokat a középiskolákban, melyek az elsősorban angolszász területen népszerü

Azt a kérdést, hogy a megjelölt tartalmak oktatását milyen módszerrel lehet és érdemes általános vagy középiskolás diákok számára hatékonyan megoldani, a felsóoktatási tapasztalatok alapján egyértelmúen meg lehet válaszolni. Még véletlenül sem abban a formában, ahogyan azt a jogászképzésben teszszük. Nyilván léteznek a magyar jogászképzésben is olyan megoldások, melyek a "poroszos" hagyományoktól eltéróen, interaktív módon vezetik be a hallgatóság egyes csoportjait a jogági rejtelmekbe, ám a számonkérés módja a leadott tananyag szigorú visszakérdezésére koncentrál továbbra is. Az ilyen jellegú oktatási módszer a közoktatásban csupán arra lehet alkalmas, hogy a diákokat a jog világától elidegenítse. Street Law programok mintájára kívánnak jogi ismereteket átadni a közoktatásban. Az 1970-es években a Georgetown Egyetem jogi karán kidolgozott Street Law programok ugyan a középiskolában kezdődtek, ám tevékenységük nem csupán azokra korlátozódva kívánja azóta is a társadalom széles 
rétegeivel megismertetni a jog alapjait olyan formában, hogy az a laikusok számára is érdekes és emészthető legyen. A 'Street Law' kifejezés arra utal, hogy az átadni kívánt ismeretanyag gyakorlatias, és a hétköznapi igényeknek megfelelö.

Az OBH-ból kiinduló kezdeményezés Magyarországon a Street Law programoktól annyiban különbözik, hogy az ismeretterjesztő tevékenységet gyakorló bírák végzik, akik önkéntes alapon, az osztályfőnöki órák keretében tanítanak középiskolásokat. A diákok emellett bírósági épületeket, börtönöket, tárgyalásokat látogathatnak és perszimuláció segítségével mélyíthetik ismereteiket. Míg a Street Law elsősorban erre kiképzett joghallgatókra épít, addig a magyar kísérlet gyakorló bírákra, bírósági titkárokra (legújabban gyakorló ügyészekre), akik a joghallgatóknál nyilván mélyebb ismeretekkel rendelkeznek, és a praxisból hozott példákkal tehetik érdekessé az órákat. Ami a programból egyelöre hiányzik, az éppen azon módszertani megalapozottság, ami a Street Law programok nagy értéke, és ami az oktatásban járatlanabb gyakorló jogászok számára is kapaszkodót nyújthatna ahhoz, hogy miként lehet interaktív módon érdekes órákat tartani úgy, hogy az egyúttal hatékonyan emelje a diákok jogismeretének szintjét. Érdemes lenne továbbá a kurzusok előtt és azok végén a tudásszint felmérésére is sort keríteni, aminek szükségességére iskolaigazgatók is felhívták figyelmünket. A kísérleti és kontrollcsoport körben végzett felmérés alapján lehetne szükség szerint tananyag- és módszerfejlesztésbe kezdeni.

A keretek Magyarországon jelenleg adottak tehát, hogy egy már müködő rendszer adaptálásával, továbbfejlesztésével mélyülhessen a közoktatásban részt vevő diákok jogismerete, aminek szükségességéről kívántuk meggyőzni a hallgatóságot. Az így megszerzett tudás a diákok számára értelmezhetővé teszi a más tantárgyak tanulása során elsajátított jogi ismereteket, egyúttal kiegészítheti azokat a fent említett, a közoktatásban nem tárgyalt területekre vonatkozó információkkal.

Az általam megkérdezett intézményvezetők a diákok elégedettségéről számoltak be. A programhoz csatlakozó középiskolák száma egyre bővül, és egyelőre nem látszik, hogy e kezdeményezés „kifáradna”. Ugyanakkor a magunk részéről a legnagyobb veszélyt abban látjuk, hogy fenntartható lehet-e egy olyan rendszer, mely az amúgy is rendkívül leterhelt bíráktól vagy ügyészektől vár el hosszú távon karitatív tevékenységet. E probléma kiküszöbölése érdekében nem csupán a középiskolákat, hanem a hazai jogász társadalom minél szélesebb körét érdemes rávenni arra, hogy e programba bekapcsolódjon.

\section{Irodalomjegyzék}

Bencsik Péter és Horváth Levente Attila (2007): Történelem 8. osztály. A huszadik század története. Állampolgári ismeretek. Mozaik Kiadó, Szeged.

Bíró Endre (1998): Jog a pedagógiában. Jogismeret Alapítvány, Budapest.

Eberwein, H. J. (2008): Raising legal literacy in public schools, a call for principal leadership: A national study of secondary principals' knowledge of public school law. Doktori disszertáció. Kézirat. University of Massachusetts at Amherst.

Eckhart Ferenc (1936): A jog-és államtudományi kar története 1667-1935. PPT, Budapest.

Ferge Zsuzsa (1984): Az iskolarendszer és az iskolai tudás társadalmi meghatározottsága. Akadémiai Kiadó, Budapest.
Fischer, L., Schimmel, D. és Stellman, L. (2007): Teachers and the law. 7. kiadás. Allyn \& Bacon, Boston.

Gajda, R. (2008): States' expectations for teachers' knowledge about school law. Action in Teacher. Education, 30. 2. sz. 15-24. DOI: 10.1080/01626620.2008.10463488

Gajduschek György és Fekete Balázs (2014): A jogismeret változása az elmúlt közel fél évszázadban. Összehasonlító elemzés Kulcsár Kálmán 1965-ös empirikus kutatása alapján. Kézirat.

Galichet, F. (2005): L'éducation à la citoyenneté dans les programmes d'enseignement français nécessairement laïc et leur mise en oeuvre. Colloque international salésien de Lyon (20-24 août 2005). http://philogalichet.fr/wp-content/uploads/2011/10 /L\%C3\%A9ducation-civique-en-France1.pdf 
Joyce, Sh. (2000): Keeping schools from being sued. Education Digest, 65. 2. sz. 4-8.

Kelemen László (2009): Joghallgatók a jogról. Sprinter, Budapest.

Kormány Attila (2014): Jogismeret, jogtudat, jogkövetés. In: Fleck Zoltán és mtsai: Jogszociológiai elöadások. ELTE Eötvös Kiadó, Budapest. 127-151.

Kulcsár Kálmán (1967): A jogismeret vizsgálata. MTA JTI, Budapest.

Kukorelli István és Pozsár-Szentmiklósy Zoltán (2010): Állampolgári ismeretek. Mozaik Kiadó, Szeged.

Ligeti György és Márton Izabella (2001): Diákjogok és pedagógusjogok az iskolában. Kutatási beszámoló. Az Oktatási Minisztérium Oktatási Jogok Miniszteri Biztosának Hivatala megbízásából a Kurt Lewin Alapítvány által a 2000-2001-es tanév során végzett országos szociológiai kutatás alapján. http://www. oktbiztos.hu/kutatasok/diakjog/dj 00.htm
Militello, M., Schimmel, D. és Eberwein, H. J.(2009). If they knew they, would change: How legal knowledge impacts principals' practice. NASSP Bulletin. 93. 1. sz. 27-52. DOI: 10.1177/0192636509332691

Nagy Zsolt (2007): A jogi oktatás fejlödése és aktuális kérdései. Pólay Elemér Alapítvány, Szeged.

Sajó András (1980): Jogkövetés és társadalmi magatartás. Akadémiai Kiadó, Budapest.

Sajó András (1986): Látszat és valóság a jogban. Közgazdasági és Jogi Kiadó, Budapest. 273-312.

Schimmel, D., Fischer, L. és Stellman, L. (2008): School law: What every educator should know. Pearson Education, Inc, Boston, MA.

Schimmel, D. és Militello, M. (2007): Teachers' knowledge and perceptions of the law. Educational Review, 77. 3. sz. 257-284.

Visegrádi Antal és Schadt Mária (2000): Egyetemi hallgatók jogtudata, jogismerete. Jogelméleti Szemle, 1. sz. jesz.ajk.elte.hu/viseg1.html 